\title{
Reduced expression of uncoupling proteins- 2 and -3 in adipose tissue in post-obese patients submitted to biliopancreatic diversion
}

Roberto Vettor, Geltrude Mingrone ${ }^{1}$, Melania Manco ${ }^{1}$, Marnie Granzotto, Gabriella Milan, Alessandro Scarda, Annamaria Lombardi, Aldo Virgilio Greco ${ }^{1}$ and Giovanni Federspil

Endocrine Metabolic Laboratory, Internal Medicine, Department of Medical and Surgical Sciences, University of Padua, via Ospedale 105, 35128 Padua, Italy and ${ }^{1}$ Department of Medicine, Catholic University S. Cuore, Largo A Gemelli, 8-00168 Rome, Italy

(Correspondence should be addressed to R Vettor; Email: roberto.vettor@unipd.it)

(Roberto Vettor and Geltrude Mingrone contributed equally to this work)

\begin{abstract}
Objective: Little is known about the physiological role and the regulation of uncoupling proteins- 2 and -3 (UCP-2 and -3) in adipose tissue. We investigated whether the expression of UCP-2 and -3 in adipose tissue was affected by weight loss due to a biliopancreatic diversion (BPD) and related to the daily energy expenditure (24-h EE).

Design: Ten morbidly obese subjects (mean body mass index \pm s.E.M. $=49.80 \pm 2.51 \mathrm{~kg} / \mathrm{m}^{2}$ ) were studied before and $18 \pm 2$ months after BPD.

Methods: We determined body composition using tritiated water and 24-h EE in a respiratory chamber. Adipose tissue UCP-2 and -3 mRNA, plasma insulin, glucose, free fatty acids (NEFA), free triiodothyronine (FT3), free thyroxine (FT4) and leptin were assayed before and after BPD.

Results: BPD treatment resulted in a marked weight loss $(P<0.001)$ mainly due to a fat mass reduction. A significant decrease in 24-h EE/fat-free mass (FFM) $(P<0.05)$ and in UCP-2 $(P<0.05)$ and UCP-3 $(P<0.05)$ mRNA was observed. A significant reduction in plasma insulin, glucose, NEFA, FT3, FT4 and leptin was seen after BPD. The decline in plasma leptin and FFA was tightly correlated with the decrease in both UCP-2 and -3. A significant correlation was found between changes in FT3 and variations in 24-h EE $(r=0.64, P<0.05)$. In a multiple-regression analysis changes in 24-h EE/FFM after BPD were significantly correlated with changes in UCP-3 expression $(P<0.05)$.

Conclusion: These findings suggest that UCPs in adipose tissue may play a role in the reduction in 24-h EE observed in post-obese individuals.
\end{abstract}

European Journal of Endocrinology 148 543-550

\section{Introduction}

Changes in the balance between energy intake and energy expenditure may play a role in long-term body weight (BW) regulation and in the development of obesity. A relatively low energy expenditure has been implicated in future weight gain (1) as well as in promoting relapse after short-term intentional weight loss $(2-4)$. Therefore it is essential to understand better the mechanisms involved in the control of energy expenditure in obesity. Resting metabolic rate (RMR), which is the major component of the daily energy expenditure (24-h EE), is the result of complex biochemical reactions leading to a proton leak across the mitochondrial inner membrane, which results in energy dissipation because of uncoupling of oxygen consumption from ATP synthesis (5). Among the mitochondrial carrier proteins playing a major role in this process, the first discovered, uncoupling protein (UCP)-1 (6), is exclusively expressed in brown adipose tissue (BAT), whose presence is quite negligible in adults (7); therefore it is unlikely that this protein may be implicated in regulation of energy expenditure in humans. Two UCP isoforms have been discovered with a high sequence homology to UCP-1. UCP-2 expression is observed in many tissues (8), while UCP3 is preferentially expressed in skeletal muscle and to a lesser extent in adipose tissue (9). Both these UCPs 
were thought to be implicated in the regulation of $\mathrm{EE}$ and may contribute to obesity $(10,11)$. More recently this role has been questioned after the observations that during fasting, a condition in which there is a clear depression of EE, UCP expression is increased in skeletal muscle (12). This apparent contradiction has been explained by the involvement of these proteins in the mitochondrial free fatty acid (NEFA) oxidation (13). Little information is currently available about factors controlling UCP-2 gene expression in human adipose tissue and the physiological role of this UCP remains still controversial.

Studies in humans have suggested a correlation between UCP-2 gene expression in white adipose tissue (WAT) and body mass index (BMI) (12). However, other authors reported that the obese had reduced UCP-2 mRNA content only in visceral adipose tissue compared with lean subjects, while no difference was observed in s.c. adipose tissue (14). The expression of UCP-2 mRNA in adipose tissue has been reported to be up-regulated by fasting for 5 days (12). However, Barbe et al. (15) reported that weight loss obtained with a modest food limitation did not influence adipose tissue UCP-2 expression. Moreover, in obese women a very-low-calorie diet treatment for a short period of time resulted in a clear decrease in UCP-3 mRNA in adipose tissue tightly correlated with changes in EE, whereas adipose tissue UCP-2 mRNA levels remained unchanged (16). These observations do not allow us to assign to UCP-2 and -3 a precise role in the reduction in EE observed during energy restriction. The reduction in RMR that follows weight loss (17) is mainly due to the decrease in fat-free mass (FFM), which represents the major determinant of EE (18). Nevertheless, the adipose organ is the predominant body compartment to be modified during a high ipocaloric diet in obese people. Thus, it is interesting to investigate if changes in adipose tissue UCP mRNA are only due to the reduction of fat mass or are also related to variations in EE.

The present study was designed to examine the levels of UCP-2 and -3 mRNA expression in human adipose tissue in a group of morbidly obese patients before and after biliopancreatic diversion (BPD) and subsequent important weight loss. Another relevant aim of this work was to relate this measure to major changes in adipose tissue and 24-h EE.

\section{Subjects and methods}

\section{Subjects}

The study groups consisted of ten (seven male and three female) severely obese subjects $(\mathrm{BMI}=49.80 \pm$ $2.51 \mathrm{~kg} / \mathrm{m}^{2}$ (range $\left.42.46-66.67\right)$ ) who were studied twice: before and $18 \pm 2$ months after BPD operation. None had impaired glucose tolerance, diabetes mellitus or any other endocrine or non-endocrine disease.
Before inclusion a physical examination was found normal. At the time of the baseline study, all subjects were on a free diet, with the following average composition: $60 \%$ carbohydrate, $30 \%$ fat, $10 \%$ protein (at least $1 \mathrm{~g} / \mathrm{kg} \mathrm{BW}$ ). This dietary regimen was maintained for 1 week prior to the study. Their BW was stable for at least 2 months prior to the investigation. After the initial study, patients were submitted to surgery consisting of a partial gastrectomy with a distal Roux-en-Y reconstruction $(19,20)$. The study protocol was approved by the Institutional Ethical Committee of the Catholic University of Rome; the nature and purpose of the study were carefully explained to all subjects before they provided their written agreement to participate.

\section{Body composition}

Anthropometric parameters were determined at time 0 and $18 \pm 2$ months after surgery. BW was measured to the nearest $0.1 \mathrm{~kg}$ by a beam scale, and height to the nearest $0.5 \mathrm{~cm}$ using a stadiometer (Holatin, Crosswell, UK). Total body water (TBW) was determined using $0.19 \mathrm{~Bq}$ of tritiated water in $5 \mathrm{ml}$ saline solution administered as an i.v. bolus injection (21). Blood samples were drawn before and $3 \mathrm{~h}$ after the injection. Radioactivity was determined in duplicate on $0.5 \mathrm{ml}$ plasma using a Beta-scintillation counter (Model 1600TR; Canberra-Packard, Meriden, CT, USA). Corrections were made $(5 \%)$ for non-aqueous hydrogen exchange (22); water density at body temperature was assumed to be $0.99371 \mathrm{~kg} / \mathrm{l}$. TBW (kg) was computed as tritiated water dilution space (liters) $\times 0.95 \times 0.99371$. The within-subject coefficient of variation $(\mathrm{CV})$ for this method is $1.5 \%(23)$. FFM in $\mathrm{kg}$ was obtained by dividing the TBW by 0.732 (24).

\section{Twenty-four hour EE}

The measurement of energy expenditure in a respiratory chamber was performed. Subjects entered the chamber in the morning after an overnight fast and remained there for $24 \mathrm{~h}$. Subjects were fed a standardized diet with the amount of calories calculated according to previously determined equations to achieve energy balance. Meals were provided at 0800, 1200, 1700 and $2000 \mathrm{~h}$. The rate of energy expenditure was measured continuously, calculated for each $15 \mathrm{~min}$ interval. Spontaneous physical activity was detected by radar sensors and expressed as the percentage of time over the $24 \mathrm{~h}$ period in which activity was detected. Carbon dioxide production $\left(\mathrm{VCO}_{2}\right)$ and oxygen consumption $\left(\mathrm{VO}_{2}\right)$ were calculated at 15 min intervals, summed for the $24 \mathrm{~h}$ in the chamber. The $24 \mathrm{~h}$ respiratory quotient (24-RQ) was calculated as the ratio of 24-h $\mathrm{VCO}_{2}$ and 24-h $\mathrm{VO}_{2}$ and adjusted for the 24-h energy balance ((24-h energy intake) - (24-h EE) during the stay in the chamber) in a multiple-regression analysis, 
as previously described (25). Results are presented as $\mathrm{kcal} / 24 \mathrm{~h}$ and after normalization to FFM (kcal/24h per $\mathrm{kg})$.

\section{Hyperinsulinemic euglycemic clamp}

Insulin sensitivity was determined in all subjects after an overnight fast by the euglycemic insulin clamp technique with an insulin infusion rate of $7 \mathrm{pmol} / \mathrm{min}$ per kg. Whole-body glucose uptake (M-value, in $\mathrm{mg} / \mathrm{kgBW} / \mathrm{min}$ ) was determined by averaging the exogenous glucose infusion rates during the last $40 \mathrm{~min}$ of the clamp, and correcting them for the glucose space (26).

\section{Biochemical analysis}

Plasma glucose levels were measured by a glucose oxidase method (Beckman, Fullerton, CA, USA). NEFA levels were determined using a commercial kit (Boehringer-Mannheim KK, Tokyo, Japan).

Serum immunoreactive insulin was assayed by using microparticle enzyme immunoassay (Abbott, Pasadena, CA, USA). Thyrotropin (TSH), free thyroxine (FT4) and free triiodothyronine (FT3) were measured by automated chemiluminescence methods (ACS 180 SE; Bayer, Milan, Italy); serum leptin was measured with a kit from Linco Research, Inc. (St Charles, MO, USA). To avoid interassay variability, all specimens for a given substance were run in a single assay.

\section{Adipose tissue biopsies}

Biopsies were obtained under local anesthesia with lidocaine from the s.c. adipose tissue obtained by needle aspiration in the vastus lateralis muscle region. Tissue samples were washed to remove blood, immediately frozen in liquid nitrogen and stored at $-80{ }^{\circ} \mathrm{C}$ for further analysis of UCP-2 and -3 mRNA levels. Biopsies were obtained before and after BPD surgical treatment.

\section{Isolation of RNA and RT-PCR determination of UCP-2 and -3 mRNA}

Total RNA was isolated from adipose tissue using the RNAzol method (TEL-TEST, Inc., Friendswood, TX, USA). The concentration and purity of RNA were determined by absorbance at 260 and $280 \mathrm{~nm}$. All the samples had a 260 to 280 absorbance ratio of about 2.0.

RNA was treated for $1 \mathrm{~h}$ at $37^{\circ} \mathrm{C}$ with $1 \mathrm{U}$ RNAse-free DNAse I/ $\mu \mathrm{g}$ RNA in $10 \mu \mathrm{l}$ buffer containing $40 \mathrm{mmol} / \mathrm{l}$ Tris $-\mathrm{HCl}$, pH 8.0 and $10 \mathrm{mmol} / \mathrm{l} \mathrm{MgSO}_{4}$ and $1 \mathrm{mmol} / \mathrm{l}$ $\mathrm{CaCl}_{2}$. Two micrograms of total RNA were reverse-transcribed with $200 \mathrm{U}$ Moloney murine leukemia virus reverse transcriptase (Promega Corporation, Madison, WI, USA) and $20 \mathrm{U}$ RNAsin ribonuclease inhibitor in $50 \mu \mathrm{l}$ buffer containing dNTP $\operatorname{mix}(0.5 \mathrm{mmol} / \mathrm{l}$ each $)$ and $100 \mathrm{ng}$ oligo $(\mathrm{dT})_{15}$ primer (Promega) in $50 \mathrm{mmol} / \mathrm{l}$ Tris- $\mathrm{HCl} \mathrm{pH} \mathrm{8.3,} 75 \mathrm{mmol} / \mathrm{l} \mathrm{KCl,} 3 \mathrm{mmol} / \mathrm{l} \mathrm{MgCl}_{2}$ and $10 \mathrm{mmol} / \mathrm{l}$ dithiothreitol. PCR was performed using Hot Star Taq DNA polymerase (Qiagen GmbH, Hilden, Germany) in $25 \mu \mathrm{l}$ standard buffer with $1.5 \mathrm{mmol} / \mathrm{l}$ $\mathrm{MgCl}_{2}, 200 \mu \mathrm{mol} / \mathrm{l}$ each dNTP and $40 \mathrm{pmol}$ of each sense and antisense specific oligonucleotide primer. The primer sequences were chosen using OMIGA 2.0 and were 5'-TAAAGACCTCTATGCCAACACAGT-3' and $5^{\prime}$-CACGATGGAGGGGCCGGACTCATC- $3^{\prime}$ for $\beta$-actin, 5'-CTACTGCCACTGTGAAGTTTC-3' and 5'-TCGGGCAATGGTCTTGTAGG-3' for UCP-2, 5'-ACAGATGTGGTGAAGGTCCG-3' and 5' -TACGAACATCACCACGTTCC-3' for UCP-3. Amplification products were of 241, 472 and 468 bp respectively.

The primers for $\beta$-actin were added at the tenth cycle of each PCR amplification to avoid a plateau situation. All the genes were amplified using 30 cycles at $94^{\circ} \mathrm{C}$ for $30 \mathrm{~s}, 60^{\circ} \mathrm{C}$ for $30 \mathrm{~s}$ and $72^{\circ} \mathrm{C}$ for $30 \mathrm{~s}$, followed by $5 \mathrm{~min}$ final extension at $72^{\circ} \mathrm{C}$.

After amplification, $10 \mu \mathrm{l}$ reaction mixture were separated by electrophoresis ( $1 \%$ agarose gel in Trisborate-EDTA buffer), visualized using ethidium bromide staining, revealed with Image Master VDS (Amersham Pharmacia Biotech Europe $\mathrm{GmbH}$, Freiburg, Germany) and densitometrically analyzed with Image Master Total Lab 1.00 software (Amersham Pharmacia).

The number of cycles for the semiquantitative RT-PCR analysis and the conditions of the reaction temperature were estimated to be optimal for a linear relationship between the amount of input template and the amounts of PCR product generated over a significant concentration range: 20-100 ng from total RNA. In particular the linearity of the RT-PCR amplifications for all the tested genes was measured at 15,30 and 40 cycles (data not shown).

Levels of mRNA were expressed as the ratio of signal intensity for the target genes relative to that for $\beta$-actin. The RT-PCR analyses were performed three times on the same sample; the intra-assay $\mathrm{CV}$ was $<5 \%$.

\section{Statistical analysis}

Data are shown as means \pm S.E.M. and one-way ANOVA was used to compare before and after values $(P<0.05$ was considered significant). Single-linear and multipleregression analyses were performed. All analyses were performed with STATISTICA for Windows package (StatSoft, Inc., Tulsa, OK, USA).

\section{Results}

\section{Effects of BPD on body composition and 24-h EE}

After BPD the subjects had lost around 32\% of their initial BW (mean weight loss $44.89 \pm 5.94 \mathrm{~kg}$, 
range $22-80 \mathrm{~kg})$. Changes in body composition are reported in Table 1. EE expressed in absolute terms $(-721.56 \pm 135.35 \mathrm{kcal} / 24 \mathrm{~h})$ or normalized by FFM $(-6.51 \pm 1.27 \mathrm{kcal} / 24 \mathrm{~h}$ per $\mathrm{kg})$ was significantly reduced after BPD, as reported in Table 2 .

\section{Insulin sensitivity}

A significant reduction in plasma insulin, glucose, NEFA and triglycerides was seen after BPD (Table 3). On the clamp, insulin-mediated whole-body glucose uptake that appeared markedly impaired before treatment was significantly improved after weight loss in the BPD group (Table 3).

\section{Leptin and thyroid hormones}

After BPD (18 \pm 2 months) we observed a significant fall in leptin plasma levels $(-61 \%)$ that exceeded the percent of decrease in fat stores $(-42 \%)$ (Table 3$)$. Table 3 shows the changes in thyroid hormones before and after weight reduction. Both FT3 and FT4 declined significantly, while TSH remained unchanged.

\section{Effects of BPD on adipose tissue UCP-2 and -3 mRNA levels}

UCP-2 mRNA levels in adipose tissue were significantly reduced after weight loss by $70 \%(82.80 \pm 27.48$ vs $25.13 \pm 7.41$ arbitrary units (a.u.), $P<0.05)$ The adipose tissue level of UCP3 mRNA was reduced by $50 \%$ (96.11 \pm 15.45 vs $47.51 \pm 12.47$ a.u., $P<0.05)$ in the biopsies obtained after BPD as compared with initial values (Fig. 1).

Table 1 Anthropometric characteristics of obese subjects ( $n=10$ ) at the beginning of the study and after BPD; means \pm S.E.M. Statistics were performed by one-way ANOVA.

\begin{tabular}{lrrr}
\hline & Before BPD & After BPD & $\boldsymbol{P}$ value \\
\hline $\mathrm{BW}(\mathrm{kg})$ & $135.80 \pm 6.46$ & $92.30 \pm 5.89$ & 0.00002 \\
$\mathrm{BMI}\left(\mathrm{kg} / \mathrm{m}^{2}\right)$ & $49.80 \pm 2.51$ & $34.15 \pm 2.90$ & 0.00002 \\
$\mathrm{FM}(\mathrm{kg})$ & $62.50 \pm 3.24$ & $26.60 \pm 3.59$ & 0.00001 \\
FM $(\%)$ & $45.98 \pm 0.72$ & $26.08 \pm 5.21$ & 0.00257 \\
FFM $(\mathrm{kg})$ & $73.30 \pm 3.49$ & $65.70 \pm 3.68$ & 0.02196 \\
FFM $(\%)$ & $54.02 \pm 0.72$ & $71.87 \pm 2.42$ & 0.00001 \\
\hline
\end{tabular}

FM, fat mass.

Table 2 Effects of BPD on changes in the energy metabolism profile as assessed by a calorimetric chamber; means \pm S.E.M. of 10 subjects. Statistics were performed by one-way ANOVA.

\begin{tabular}{lccc}
\hline & Before BPD & After BPD & $\boldsymbol{P}$ value \\
\hline $\mathrm{VO}_{2}(\mathrm{ml} / \mathrm{min})$ & $359.33 \pm 18.94$ & $263.69 \pm 7.69$ & 0.00037 \\
$\mathrm{VCO}_{2}(\mathrm{ml} / \mathrm{min})$ & $284.67 \pm 15.58$ & $225.66 \pm 5.84$ & 0.00198 \\
$\mathrm{RQ}$ & $0.79 \pm 0.00$ & $0.86 \pm 0.01$ & 0.00001 \\
$\mathrm{EE}(\mathrm{kcal} / 24 \mathrm{~h})$ & $2563.10 \pm 174.27$ & $1878.50 \pm 92.48$ & 0.00273 \\
$\mathrm{EE} / \mathrm{FFM}(\mathrm{kcal} / 24 \mathrm{~h} / \mathrm{kg})$ & $34.95 \pm 1.52$ & $28.81 \pm 0.81$ & 0.00062 \\
$\mathrm{~N}_{2}(\mathrm{~g} / 24 \mathrm{~h})$ & $10.39 \pm 0.46$ & $13.70 \pm 0.40$ & 0.00012 \\
\hline
\end{tabular}

Table 3 Effects of BPD on changes in the endocrine and metabolic parameters; means \pm S.E.M. of 10 subjects. Statistics were performed by one-way ANOVA.

\begin{tabular}{lccc}
\hline & Before BPD & After BPD & $\boldsymbol{P}$ value \\
\hline Glucose $(\mathrm{mg} / \mathrm{dl})$ & $90.90 \pm 1.73$ & $72.20 \pm 0.76$ & $<0.0001$ \\
Tryglycerides $(\mathrm{mg} / \mathrm{dl})$ & $181.90 \pm 6.25$ & $88.90 \pm 4.33$ & $<0.0001$ \\
NEFA $(\mu \mathrm{mol} / \mathrm{l})$ & $948.80 \pm 66.17$ & $480.80 \pm 34.94$ & 0.00001 \\
Insulin $(\mu \mathrm{U} / \mathrm{ml})$ & $30.40 \pm 2.14$ & $9.10 \pm 1.23$ & $<0.0001$ \\
M-value $(\mathrm{mg} / \mathrm{kg} \mathrm{BW} / \mathrm{min})$ & $2.34 \pm 0.18$ & $6.28 \pm 0.48$ & 0.00004 \\
Leptin $(\mathrm{ng} / \mathrm{ml})$ & $46.10 \pm 3.03$ & $17.67 \pm 1.71$ & 0.00003 \\
TSH $(\mathrm{mU} / \mathrm{l})$ & $1.76 \pm 0.22$ & $2.00 \pm 0.21$ & $\mathrm{~ns}$ \\
FT3 $(\mathrm{pmol} / \mathrm{l})$ & $2.85 \pm 0.07$ & $2.31 \pm 0.23$ & 0.04003 \\
FT4 $(\mathrm{pmol} / \mathrm{l})$ & $13.35 \pm 0.58$ & $10.99 \pm 0.55$ & 0.00035 \\
\hline
\end{tabular}

\section{Correlations between UCP mRNA, body composition, and 24-h EE}

Before surgery 24-h EE (kcal/24h) was significantly correlated with FFM in $\mathrm{kg}(r=0.76, P<0.01)$, FM in $\mathrm{kg}(r=0.69, P<0.05)$ and total BW $(r=0.75$, $P<0.01)$. Only UCP-3 mRNA was significantly correlated with BMI $(r=0.86, P<0.001)$, FFM $(r=0.95, \quad P<0.001), \quad \mathrm{FM} \quad(r=0.57, \quad P<0.05)$, 24-h EE $(r=0.98, P<0.001)$ and $24-\mathrm{h}$ EE/FFM $(r=0.69, P<0.05)$.

There was a positive correlation between the fall in EE and changes in BW $(r=0.93, P<0.001)$, FFM in $\mathrm{kg}(r=0.59, P<0.05)$ and $\mathrm{FM}$ in $\mathrm{kg}(r=0.92$, $P<0.001)$. Also 24-h EE/FFM positively correlated with changes in FM in $\mathrm{kg}(r=0.72, P<0.01)$.

There was also a positive correlation between the changes in adipose tissue UCP-3 mRNA and the fall in 24-h EE $(r=0.72, P<0.01)$ and 24 -h EE/FFM $(r=0.81, P<0.01)$, but not with adipose tissue UCP-2 mRNA (Table 4).

A significant correlation was found between changes in FT3 and variations in 24-h EE $(r=0.64, P<0.05)$; on the contrary no evidence existed for an influence of FT4 on calorimetric parameters. However, a significant negative correlation was observed between changes in FT4 and both UCP-2 and -3 modifications before and after weight reduction (Table 4).

Moreover, a significant correlation between changes in serum leptin levels after weight loss and the magnitude of the reduction of both 24-h EE $(r=0.84$, $P<0.01)$ and 24-h EE/FFM $(r=0.69, P<0.05)$, and either adipose tissue UCP-2 $(r=0.99$, $P<0.001)$ and UCP-3 $(r=0.72, P<0.01)$ mRNA levels was detected (Table 4 ).

The decline in plasma NEFA was significantly correlated with the decrease in both UCP-2 $(r=0.70$, $P<0.05)$ and UCP-3 $(r=0.61, P<0.05)$ mRNA levels in adipose tissue (Table 4).

Multiple-regression analysis, using changes in 24-h EE/FFM as the dependent variable and changes in UCP-3 as the independent variable, revealed that only percentage change in adipose tissue UCP-3 mRNA was independently correlated with 24-h EE/FFM when the 

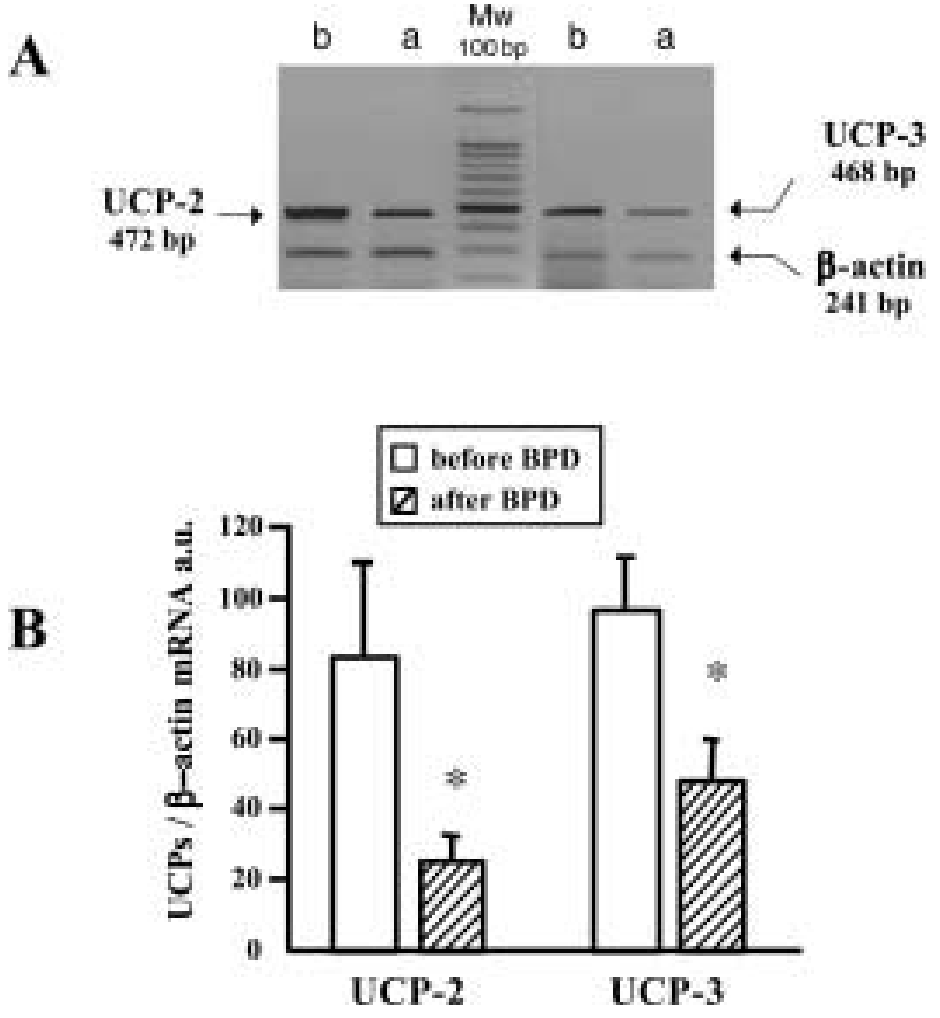

other variables (changes in BMI, insulin, NEFA and Mvalue) were taken into account in a standard regression model (adjusted $R^{2}=0.89, F=17.73, P<0.05$ ).

\section{Discussion}

Metabolic predisposition to obesity might depend not only on initial rates of EE, but also on how this parameter and the underlining control mechanisms change after weight loss. The marked weight loss produced by BPD in morbidly obese subjects significantly reduced FM, FFM and 24-h EE. Metabolic adaptation in post-obese individuals who have returned to a normal BW or have decreased their BW considerably and maintained the weight loss over months is commonly accompanied by a small reduction in EE. This phenomenon might be amplified after a more rapid decrease in BW (27), as in our experimental conditions. However, even small differences in EE can have an important influence on BW over the longterm (1) thus explaining, at least in part, the high rate of weight relapse after dieting in obese people. The decline in total EE strongly depends on changes in RMR that can be explained by a reduction in FFM (4). This is the case also in our experiments in which a significant correlation is present between changes in FFM and 24-h EE. It is widely accepted that skeletal muscle plays the major role in the regulation of RMR in humans (18), but also FM has been considered as a significant, independent predictor of this parameter

\begin{abstract}
Figure 1 Changes in UCP-2 and -3 expression in adipose tissue before and after BPD. (A) RT-PCR products of representative samples of one subject before (b) and after (a) BPD were resolved on agarose gel together with the $100 \mathrm{bp}$ molecular weight ladder (Mw), the $500 \mathrm{bp}$ band of which is present at triple the intensity of the other fragments. (B) UCP mRNA levels means \pm S.E.M.) of ten subjects before and after BPD were compared. Statistics was performed by one-way ANOVA. ${ }^{*} P<0.05$.
\end{abstract}

(28), therefore we cannot exclude the possibility that relevant modifications in fat mass and in molecular factors controlling fat cell energy metabolism (i.e. UCP-2 and -3) might influence whole-body EE. Before surgery, 24-h EE was closely correlated with BW, BMI, FM and FFM and with the mRNA levels of UCP-3. After weight loss, a positive correlation was also found between the fall in 24-h EE and changes

Table 4 Correlations between the rate of decrease of UCP-2 and -3 expression in adipose tissue and variations in the considered parameters before and after BPD. Statistics was performed by single linear regression analysis.

\begin{tabular}{|c|c|c|c|c|}
\hline \multirow{2}{*}{$\Delta$} & \multicolumn{2}{|c|}{$\Delta$ UCP-2 (a.u.) } & \multicolumn{2}{|c|}{$\Delta$ UCP-3 (a.u.) } \\
\hline & $r$ value & $P$ value & $r$ value & $P$ value \\
\hline BW (kg) & -0.29 & ns & 0.72 & $<0.01$ \\
\hline BMI $\left(\mathrm{kg} / \mathrm{m}^{2}\right)$ & -0.54 & ns & 0.52 & ns \\
\hline FFM (kg) & -0.75 & $<0.01$ & 0.23 & ns \\
\hline FM $(\mathrm{kg})$ & 0.17 & ns & 0.91 & $<0.001$ \\
\hline EE (kcal/24 h) & -0.16 & ns & 0.72 & $<0.01$ \\
\hline EE/FFM (kcal/24 h/kg) & 0.52 & ns & 0.81 & $<0.01$ \\
\hline Glucose (mg/dl) & -0.80 & $<0.01$ & -0.75 & $<0.01$ \\
\hline $\operatorname{NEFA}(\mu \mathrm{mol} / \mathrm{l})$ & 0.70 & $<0.05$ & 0.61 & $<0.05$ \\
\hline Insulin $(\mu \mathrm{U} / \mathrm{ml})$ & -0.52 & ns & 0.43 & ns \\
\hline M-value (mg/kg BW/min) & 0.40 & ns & -0.62 & $<0.05$ \\
\hline FT3 (pmol/l) & -0.50 & ns & 0.43 & ns \\
\hline FT4 (pmol/l) & -0.64 & $<0.05$ & -0.94 & $<0.001$ \\
\hline TSH (mU/l) & 0.08 & ns & 0.73 & $<0.01$ \\
\hline Leptin (ng/ml) & 0.99 & $<0.001$ & 0.72 & $<0.01$ \\
\hline
\end{tabular}


in FM and FFM; moreover, a clear reduction in both adipose tissue UCP-2 and -3 mRNA levels was observed, but only the change in adipose tissue UCP-3 mRNA was independently correlated with the decrease in 24-h EE/FFM. However, divergent results have previously been described concerning the correlation between UCP gene expression, BMI and changes in $\mathrm{BW}(10,12,15,16,29-31)$.

It has been reported that the reduction of thermogenesis that occurs during weight loss is somewhat determined by the degree of depletion of the fat stores and that it persists during subsequent weight recovery, with the energy thus conserved being directed at accelerating the refill of the fat stores (32). Lipogenesis and lipolysis in adipose tissue are tightly dependent on ATP levels (33) and the respiratory uncoupling may therefore contribute to the control of fat cell energy metabolism (34-37). As a matter of fact, pharmacological treatments that induce the expression of UCPs in WAT are able to reduce adiposity.

The correlation between changes in the expression of UCP-2 and -3 in WAT and the modifications in fat mass we found are in keeping with this view, even if WAT is not a major thermogenic tissue in humans. Moreover, since UCP-2 is expressed at a much higher level than $\mathrm{UCP}-3$ in adipose tissue it seems questionable if its variations in this organ may play a major role in EE. Nevertheless, in our experimental conditions only changes produced by BPD in adipose tissue UCP-3 mRNA seem to contribute independently to the variation in EE.

However, the putative thermogenetic role of these UCPs has been recently questioned and several findings indicate that NEFA might be involved in the control of UCP expression (13). As a matter of fact, the increased gene expression of UCP-3 in adipose tissue and skeletal muscle in rodents $(38,39)$ and humans $(12)$ produced by a prolonged fast is probably due to the accompanying increase in circulating NEFA release from adipocytes and their oxidation in muscle.

In our experimental model we observed an important reduction in FM and a concomitant decline in plasma NEFA, thus leading to a decrease in both UCP-2 and -3 adipose tissue expression. In agreement with this view, we recently observed that the increase in circulating NEFA levels during Intralipid plus heparin infusion in healthy subjects increased both UCP-2 and -3 in subcutaneous fat (40). The BPD treatment and the Intralipid infusion represent two different physiological conditions: the former is characterized by an increased release of NEFA from adipocytes to supply muscle energy requirements, while the latter is characterized by an enhanced flux of NEFA preferentially channeled to adipose tissue. Since it has been recently described that, in the fasting state, adipose tissue UCP-2 expression correlated inversely with epigastric venous fatty acids concentration (31), the reduced UCP expression may be considered therefore as the consequence of an increased lipid fuel flux leaving adipose tissue.
Different hormones are known to regulate the mRNA expression of UCPs; leptin, thyroid hormones and $\beta-3-$ adrenergic agonists all appear able to stimulate UCP mRNA expression in adipose tissue $(34,41)$.

FT3 produces an organ-specific enhancement of UCP-2 and -3 mRNA in rats, namely in the heart, BAT, WAT and skeletal muscle $(42,43)$. Muscle UCP-3 levels were found to be decreased in hypothyroid rats and increased considerably in hyperthyroid rats (34). Recently it has seen shown that, in humans, a doubling of plasma FT3 levels leads to an up-regulation of UCP-2 and -3 mRNA levels in adipose tissue (44). These data obtained in animals and in humans suggest that UCP-2 and -3 could mediate, at least to some extent, the effects of T3 on energy metabolism (45). We confirmed that changes in FT3 and variations in 24-h EE may be linked together. However, we did not observe any significant correlations between changes in serum concentrations of FT3 and the adipose tissue UCP-2 and -3 mRNA expression, while a significant negative correlation was observed between changes in FT4 and both UCP-2 and -3 modifications. These apparent contradictory results may be explained by the fact that data we collected either before surgery or after weight loss are consistent with an euthyroid status of the patients we analyzed, and we cannot exclude the possibility that a more marked fall in thyroid hormone concentrations may have a different impact on UCP gene expression.

The significant correlation we observed between changes in serum leptin levels and differences in 24-h EE also confirms previous data, even if in this field conflicting results have been obtained. A link between leptin levels and EE was also recently suggested in a group of overweight and obese women in whom a negative correlation between RMR and leptin levels was found after controlling for FM and FFM. Moreover, in a multiple-regression analysis, leptin contributed significantly to RMR, independently of body composition (46). A direct thermogenic effect of leptin was recently demonstrated in skeletal muscle (47), but so far no clear evidence for a direct effect of leptin on adipose energy metabolism has been reported.

In our study we were able to detect a significant correlation between the decrease in serum leptin concentrations after weight loss and either adipose tissue UCP-2 and -3 mRNA levels, thus supporting the idea of a role for leptin in controlling UCP expression also during a remarkable weight loss. As a matter of fact, it has been shown that leptin increases UCP-2 mRNA in pancreatic islets and in WAT (48). Moreover adipose tissue UCP-2 and skeletal muscle UCP-3 mRNA levels were increased upon a central nervous system leptin infusion in rats $(49,50)$.

In conclusion, the change in 24-h EE observed after BPD was closely correlated with the change in FM and FFM. Prolonged energy restriction caused by BPD 
and the subsequent weight loss affects both UCP-2 and -3 mRNA in adipose tissue. Changes in UCP-3 expression may contribute to the variation in 24-h EE. However, we cannot exclude the possibility that the decrease in the UCP expression may be simply the result of changes in the fat cell lipid metabolism. Our data further suggest a role for leptin in the control of energy metabolism either directly or through its effects on UCP-2 and -3, whose impact on the development of obesity and whose link with the frequent relapse after dieting still remain to be elucidated.

\section{Acknowledgements}

The excellent technical assistance of Ms Marilena Tormene and Sonia Leandri is greatly appreciated. This work was supported by a grant of MURST (Ministero della Ricerca Scientifica e Tecnologica) no. 2001065883_003.

\section{References}

1 Ravussin E, Lillioja S, Knowler WC, Christin L, Freymond D, Abbott WG et al. Reduced rate of energy expenditure as a risk factor for body-weight gain. New England Journal of Medicine $1988318467-472$.

2 Buscemi S, Caimi G \& Verga S. Resting metabolic rate and postabsorptive substrate oxidation in morbidly obese subjects before and after massive weight loss. International Journal of Obesity and Related Metabolic Disorders 199620 41-46.

3 Heshka S, Yang MU, Wang J, Burt P \& Pi-Sunyer FX. Weight loss and change in resting metabolic rate. American Journal of Clinical Nutrition $1990 \mathbf{5 2} 981-986$.

4 Ravussin E, Burnand B, Schutz Y \& Jequier E. Energy expenditure before and during energy restriction in obese patients. American Journal of Clinical Nutrition 198541 753-759.

5 Porter RK. Mitochondrial proton leak: a role for uncoupling proteins 2 and 3? Biochimica et Biophysica Acta $2001 \mathbf{1 5 0 4}$ $120-127$.

6 Bouillaud F, Ricquier D, Thibault J \& Weissenbach J. Molecular approach to thermogenesis in brown adipose tissue: cDNA cloning of the mitochondrial uncoupling protein. PNAS 1985 82 445-448.

7 Lean ME, James WP, Jennings G \& Trayhurn P. Brown adipose tissue uncoupling protein content in human infants, children and adults. Clinical Science 198671 291-297.

8 Fleury C, Neverova M, Collins S, Raimbault S, Champigny O, Levi-Meyrueis $\mathrm{C}$ et al. Uncoupling protein-2: a novel gene linked to obesity and hyperinsulinemia. Nature Genetics $1997 \mathbf{1 5}$ 269-272.

9 Boss O, Samec S, Paoloni-Giacobino A, Rossier C, Dulloo A, Seydoux J et al. Uncoupling protein-3: a new member of the mitochondrial carrier family with tissue-specific expression. FEBS Letters $1997 \mathbf{4 0 8} 39-42$.

10 Bao S, Kennedy A, Wojciechowski B, Wallace P, Ganaway E \& Garvey WT. Expression of mRNAs encoding uncoupling proteins in human skeletal muscle: effects of obesity and diabetes. Diabetes $1998471935-1940$.

11 Vidal-Puig A, Rosenbaum M, Considine RC, Leibel RL, Dohm GL \& Lowell BB. Effects of obesity and stable weight reduction on UCP2 and UCP3 gene expression in humans. Obesity Research 19997 $133-140$.

12 Millet L, Vidal H, Andreelli F, Larrouy D, Riou JP, Ricquier D et al. Increased uncoupling protein-2 and -3 mRNA expression during fasting in obese and lean humans. Journal of Clinical Investigation $19971002665-2670$.

13 Giacobino JP. Uncoupling proteins, leptin, and obesity: an updated review. Annals of the New York Academy of Sciences 2002967 398-402.

14 Oberkofler H, Liu YM, Esterbauer H, Hell E, Krempler F \& Patsch W. Uncoupling protein-2 gene: reduced mRNA expression in intraperitoneal adipose tissue of obese humans. Diabetologia $199841940-946$.

15 Barbe P, Millet L, Larrouy D, Galitzky J, Berlan M, Louvet JP et al. Uncoupling protein-2 messenger ribonucleic acid expression during very-low-calorie diet in obese premenopausal women. Journal of Clinical Endocrinology and Metabolism $1998 \mathbf{8 3}$ $2450-2453$.

16 Pedersen SB, Borglum JD, Kristensen K, Norrelund H, Otto J, Jorgensen L et al. Regulation of uncoupling protein (UCP) 2 and 3 in adipose and muscle tissue by fasting and growth hormone treatment in obese humans. International Journal of Obesity and Related Metabolic Disorders 200024 968-975.

17 Welle SL, Amatruda JM, Forbes GB \& Lockwood DH. Resting metabolic rates of obese women after rapid weight loss. Journal of Clinical Endocrinology and Metabolism $1984 \mathbf{5 9} 41-44$.

18 Zurlo F, Larson K, Bogardus C \& Ravussin E. Skeletal muscle metabolism is a major determinant of resting energy expenditure. Journal of Clinical Investigation 199086 1423-1427.

19 Mingrone G, Henriksen FL, Greco AV, Krogh LN, Capristo E, Gastaldelli A et al. Triglyceride-induced diabetes associated with familial lipoprotein lipase deficiency. Diabetes $1999 \mathbf{4 8}$ $1258-1263$.

20 Scopinaro N, Gianetta E, Civalleri D, Bonalumi U \& Bachi V. Biliopancreatic bypass for obesity: II. Initial experience in man. British Journal of Surgery $19796 \mathbf{6 6} 618-620$.

21 Moore FD, Olesen KH, McMurrey JD, Parker HV, Ball MR \& Boyden CM. The Body Cell Mass and its Supporting Environment. Philadelphia: WB Saunders, 1963.

22 Culebras JM \& Moore FD. Total body water and the exchangeable hydrogen. I. Theoretical calculation of nonaqueous exchangeable hydrogen in man. American Journal of Physiology 1977232 R54-R59.

23 Heymsfield SB, Lichtman S, Baumgartner RN, Wang J, Kamen Y, Aliprantis A et al. Body composition of humans: comparison of two improved four-compartment models that differ in expense, technical complexity, and radiation exposure. American Journal of Clinical Nutrition $1990 \mathbf{5 2} 52-58$.

24 Bonora E, Del Prato S, Bonadonna RC, Gulli G, Solini A, Shank ML et al. Total body fat content and fat topography are associated differently with in vivo glucose metabolism in nonobese and obese nondiabetic women. Diabetes 199241 1151-1159.

25 Jequier E, Acheson K \& Schutz Y. Assessment of energy expenditure and fuel utilization in man. Annual Review of Nutrition $19877187-208$.

26 DeFronzo RA, Tobin JD \& Andres R. Glucose clamp technique: a method for quantifying insulin secretion and resistance. American Journal of Physiology 1979237 E214-E223.

27 Leibel RL, Rosenbaum M \& Hirsch J. Changes in energy expenditure resulting from altered body weight. New England Journal of Medicine $1995332621-628$.

28 Nielsen S, Hensrud DD, Romanski S, Levine JA, Burguera B \& Jensen MD. Body composition and resting energy expenditure in humans: role of fat, fat-free mass and extracellular fluid. International Journal of Obesity and Related Metabolic Disorders 200024 1153-1157.

29 Esterbauer H, Oberkofler H, Dallinger G, Breban D, Hell E, Krempler F et al. Uncoupling protein-3 gene expression: reduced skeletal muscle mRNA in obese humans during pronounced weight loss. Diabetologia $199942302-309$.

30 Schrauwen P, Xia J, Bogardus C, Pratley RE \& Ravussin E. Skeletal muscle uncoupling protein 3 expression is a determinant of energy expenditure in Pima Indians. Diabetes $1999 \mathbf{4 8}$ 146-149. 
31 Pinkney JH, Boss O, Bray GA, Bulmer K, Coppack SW \& Mohamed-Ali V. Physiological relationships of uncoupling protein-2 gene expression in human adipose tissue in vivo. Journal of Clinical Endocrinology and Metabolism 200085 2312-2317.

32 Dulloo AG \& Jacquet J. Adaptive reduction in basal metabolic rate in response to food deprivation in humans: a role for feedback signals from fat stores. American Journal of Clinical Nutrition $199868599-606$.

33 Kopecky J, Flachs P, Bardova K, Brauner P, Prazak T \& Sponarova J. Modulation of lipid metabolism by energy status of adipocytes: implications for insulin sensitivity. Annals of the New York Academy of Sciences 2002967 88-101.

34 Gong DW, He Y, Karas M \& Reitman M. Uncoupling protein-3 is a mediator of thermogenesis regulated by thyroid hormone, beta3adrenergic agonists, and leptin. Journal of Biological Chemistry 1997272 24129-24132.

35 Yoshida T, Sakane N, Umekawa T, Kogure A, Kondo M, Kumamoto $\mathrm{K}$ et al. Nicotine induces uncoupling protein 1 in white adipose tissue of obese mice. International Journal of Obesity and Related Metabolic Disorders 199923 570-575.

36 Himms-Hagen J, Melnyk A, Zingaretti MC, Ceresi E, Barbatelli G \& Cinti S. Multilocular fat cells in WAT of CL-316243-treated rats derive directly from white adipocytes. American Journal of Physiology. Cell Physiology 2000279 C670-C681.

37 Kopecky J, Rossmeisl M, Flachs P, Bardova K \& Brauner P. Mitochondrial uncoupling and lipid metabolism in adipocytes. Biochemical Society Transactions 200129 791-797.

38 Boss O, Samec S, Dulloo A, Seydoux J, Muzzin P \& Giacobino JP. Tissue-dependent upregulation of rat uncoupling protein-2 expression in response to fasting or cold. FEBS Letters 1997 $412111-114$.

39 Boss O, Samec S, Kuhne F, Bijlenga P, Assimacopoulos-Jeannet F, Seydoux J et al. Uncoupling protein-3 expression in rodent skeletal muscle is modulated by food intake but not by changes in environmental temperature. Journal of Biological Chemistry 1998 $2735-8$.

40 Nisoli E, Carruba MO, Tonello C, Macor C, Federspil G \& Vettor R. Induction of fatty acid translocase/CD36, peroxisome proliferatoractivated receptor-gamma2, leptin, uncoupling proteins 2 and 3 , and tumor necrosis factor-alpha gene expression in human subcutaneous fat by lipid infusion. Diabetes $200049319-324$.
41 Jezek P. Possible physiological roles of mitochondrial uncoupling proteins - UCPn. International Journal of Biochemistry and Cell Biology 200234 1190-1206.

42 Masaki T, Yoshimatsu H, Kakuma T, Hidaka S, Kurokawa M \& Sakata T. Enhanced expression of uncoupling protein 2 gene in rat white adipose tissue and skeletal muscle following chronic treatment with thyroid hormone. FEBS Letters $1997 \mathbf{4 1 8}$ $323-326$.

43 Larkin S, Mull E, Miao W, Pittner R, Albrandt K, Moore C et al. Regulation of the third member of the uncoupling protein family, UCP3, by cold and thyroid hormone. Biochemical and Biophysical Research Communications 1997240 222-227.

44 Barbe P, Larrouy D, Boulanger C, Chevillotte E, Viguerie N, Thalamas $\mathrm{C}$ et al. Triiodothyronine-mediated up-regulation of UCP2 and UCP3 mRNA expression in human skeletal muscle without coordinated induction of mitochondrial respiratory chain genes. FASEB Journal 200115 13-15.

45 Lanni A, Beneduce L, Lombardi A, Moreno M, Boss O, Muzzin P et al. Expression of uncoupling protein-3 and mitochondrial activity in the transition from hypothyroid to hyperthyroid state in rat skeletal muscle. FEBS Letters $1999 \mathbf{4 4 4} 250-254$.

46 Wauters M, Considine RV, Chagnon M, Mertens I, Rankinen T, Bouchard C et al. Leptin levels, leptin receptor gene polymorphisms, and energy metabolism in women. Obesity Research 2002 $10394-400$.

47 Dulloo AG, Stock MJ, Solinas G, Boss O, Montani JP \& Seydoux J. Leptin directly stimulates thermogenesis in skeletal muscle. FEBS Letters $2002 \mathbf{5 1 5} 109-113$.

48 Zhou YT, Shimabukuro M, Koyama K, Lee Y, Wang MY, Trieu F et al. Induction by leptin of uncoupling protein-2 and enzymes of fatty acid oxidation. PNAS 199794 6386-6390.

49 Cusin I, Zakrzewska KE, Boss O, Muzzin P, Giacobino JP, Ricquier $\mathrm{D}$ et al. Chronic central leptin infusion enhances insulin-stimulated glucose metabolism and favors the expression of uncoupling proteins. Diabetes $1998471014-1019$.

50 Scarpace PJ, Nicolson M \& Matheny M. UCP2, UCP3 and leptin gene expression: modulation by food restriction and leptin. Journal of Endocrinology 1998159 349-357.

Received 22 October 2002

Accepted 14 February 2003 